\title{
LA MUERTE POR LA PATRIA EN EL NACIONALISMO VASCO: UNA INDAGACIÓN DESDE EL SUJETO
}

\section{THE DEATH FOR THE FATHERLAND IN THE BASQUE NATIONALISM: AN INQUIRY INTO THE ACTOR}

\author{
Fernando Martínez Rueda \\ Universidad del País Vasco/Euskal Herriko Unibertsitatea, España \\ orcid.org/0000-0002-9083-2278
}

Recibido el 23-1-2017 y aceptado el 8-5-2017

\begin{abstract}
Resumen: Este artículo estudia la idea del sacrificio por la patria en el nacionalismo vasco del siglo Xx. Tomando como hilo conductor de nuestro relato la figura de Joseba Elosegi, símbolo del gudari dispuesto a entregar su vida por la patria, realizamos un recorrido histórico por el componente sacrificial del nacionalismo vasco desde los tiempos de Sabino Arana hasta la Transición a la democracia. Nuestra conclusión es que la idea del sacrificio por la patria arraigó de forma muy intensa y persistente en el imaginario abertzale debido a diferentes factores como la formulación religiosa del nacionalismo aranista, su visión agónica de la identidad vasca, la específica cultura de la guerra civil del nacionalismo vasco o la trasmisión de una memoria mitificada de la experiencia bélica. Como consecuencia de ello, todavía a finales del siglo xx el nacionalismo moderado y el radical pugnaban por el legado del gudari, símbolo del sacrificio por la patria vasca.
\end{abstract}

Palabras clave: Nacionalismo vasco, sacrificio patriótico, Joseba Elosegi, Guerra Civil, memoria histórica.

\footnotetext{
Abstract: This paper studies the idea of the patriotic sacrifice in the Basque nationalism in the 20th century. The leading figure of Joseba Elosegi - symbol of the gudari (Basque soldier) ready to give his life for the fatherland - is taken as the focus of the account. It is under review the Basque nationalism's sacrificial feature from Sabino Arana's times until the Transition to Democracy. It can be concluded that the idea of patriotic sacrifice put down roots in the Basque nationalism's imaginary very powerfully and persistently due to different fac-
} 
tors such as the religious shape of aranist nationalism, its agonizing sense of the Basque identity, the Basque nationalism's culture about Civil War and the transmission of the Civil War's memory converted into a myth. In consequence, even in the last decades of the $20^{\text {th }}$ century the moderate and the radical nationalism tried hard to get the gudari's legacy, symbol of the sacrifice for the Basque fatherland.

Keywords: Basque nationalism, patriotic sacrifice, Joseba Elosegi, Civil War, historical memory. 


\section{Introducción}

Nacionalismo y religión han mantenido una estrecha y compleja relación. En los últimos tiempos numerosas investigaciones realizadas desde diversas disciplinas como la sociología, la ciencia política o la historia han indagado sobre la naturaleza de esa relación. Estos trabajos nos informan de una interacción profunda, compleja, cambiante y enormemente diversa según los casos entre religión y nacionalismo ${ }^{1}$. Algunos de estos autores han centrado su análisis en las analogías y elementos compartidos por el nacionalismo y la religión. Así se ha descrito al nacionalismo, no como una ideología política más, sino como un movimiento que, al igual que la religión, implica una fe, una devoción y un sistema de creencias (en este caso hacia la nación sacralizada), ofrece una salvación colectiva (a través de la continuidad de la nación) y desarrolla un conjunto de prácticas rituales que cohesionan a la comunidad de creyentes-patriotas. Anthony D. Smith ha profundizado en la observación de esta analogía identificando los cuatro principales elementos que el nacionalismo sacraliza y que le confieren ese carácter religioso: el mito de la comunidad nacional como pueblo elegido; la adhesión a un territorio considerado sagrado y perteneciente a la comunidad; la idealización de un pasado glorioso, entendido como edad de oro perdida; y la creencia en el poder regenerador del sacrificio individual y colectivo para asegurar un glorioso destino nacional $^{2}$. Como ha señalado Benedict Anderson (1993:27) en relación a este último elemento sacrificial, la enorme preocupación del nacionalismo por la muerte patriótica sugiere una fuerte afinidad con el universo de lo religioso.

La idea religiosa del sacrificio - etimológicamente sacrum facere, es decir, hacer algo sagrado - por la patria ha tenido una gran relevancia en el imaginario de los nacionalismos. El relato nacionalista ha entendido la muerte por la patria como un medio para alcanzar el destino al que la nación está llamada. Se ha adaptado al credo nacionalista la idea religiosa de que la vida y la resurrección (de la nación en este caso) se engendra a partir de otra vida que se inmola. Al morir por la patria el fallecimiento se convierte en sacrificio heroico, dotando así de sentido a la muerte, de forma que el nacionalismo desempeña en este aspecto una función similar

${ }^{1}$ Greenfeld, 1996, pp. 169-19. Sponh, 2003, pp. 265-286. Zubrzycki, 2010, pp. 606-625. Brubaker, 2012, pp. 2-20. Haupt y Langewiesche, 2010. Langewiesche, 2012, pp. 75-100.

${ }^{2}$ Smith, 2000, pp. 791-814. Smith, 2003, pp. 9-19. 
a la de las religiones tradicionales. Por otro lado, la muerte por la patria refuerza el carácter sagrado de la nación al aportarle la figura del héroemártir nacional, convertido en instrumento fundamental para la nacionalización de las masas. Como señala Idith Zertal, los campos de sangre y las tumbas de los caídos en las guerras por la patria han sido materiales con los que se ha construido el sentimiento nacional. De ahí la enorme importancia que en el siglo Xx, especialmente tras la Gran Guerra, ha adquirido el culto a los caídos, pieza esencial de la religión nacionalista. Al presentar la muerte por la patria como algo glorioso, esos discursos y rituales conmemorativos han contribuido a generar un modelo de conducta, un ejemplo a imitar ${ }^{3}$.

En las siguientes páginas vamos a analizar la presencia y evolución de ese componente sacrificial en el nacionalismo vasco del siglo XX. Para abordar este tema hemos optado en lo metodológico por utilizar la perspectiva del sujeto. Creemos, con Renato Moro, que el estudio desde los actores es especialmente adecuado y útil para analizar un fenómeno político impregnado de sacralidad como es el sacrificio por la patria ${ }^{4}$. Este enfoque metodológico nos permite acercarnos a la percepción que el sujeto tiene de la muerte por la patria e indagar sobre las motivaciones del héroe nacional, encarnado en nuestro caso de estudio en la figura de Joseba Elosegi (San Sebastián, 1915-1990), gudari durante la guerra civil y activista antifranquista en la posguerra que alcanzó especial notoriedad en 1970 al tratar de inmolarse quemándose a lo bonzo en presencia de Franco. Aunque no murió, Elosegi quedó malherido y fue condenado a varios años de cárcel. Durante la Transición su figura cobró relieve político y simbólico como emblema de la entrega absoluta por la patria, siendo elegido senador por Guipúzcoa por el PNV en varias legislaturas.

Tomando como hilo conductor de nuestro relato la figura de Joseba Elosegi, nos proponemos realizar un recorrido histórico por el componente sacrificial del nacionalismo vasco. Nuestro punto de partida es el nacionalismo aranista y sus mensajes sobre el sacrificio patriótico. Observamos después el impacto de la guerra civil y su memoria mitificada en la idea de muerte por la patria. Sobre ese sustrato explicamos el intento de

${ }^{3}$ Smith, 2003, pp. 218-253; Mosse, 2016, pp. 105-146; Kapferer, 2011; Marvin y Ingle, 1999, pp. 63-97. Zertal, 2009, pp. 107-123. Para el caso de la España franquista Box, 2005, pp. 195-228; Box, 2009, pp. 55-94. Para el nacionalismo vasco radical Casquete, 2009.

${ }^{4}$ Moro, 2009, pp. 97-147. 
autoinmolación que Elosegi protagonizó en 1970 y la valoración que la comunidad nacionalista hizo de ese acontecimiento. Analizamos, por último, el papel que el nacionalismo moderado reservó en la Transición a un viejo gudari como Elosegi, convertido en héroe nacional por su disposición al sacrificio. El itinerario propuesto nos permitirá observar la intensidad y persistencia de la idea del sacrificio por la patria en el imaginario abertzale del siglo $\mathrm{xx}$.

\section{El sacrificio por la patria en el nacionalismo vasco, desde Sabino Arana hasta la guerra civil}

En los últimos años del siglo XIX y primeros del XX Sabino Arana formuló un nacionalismo religioso ${ }^{5}$ en el que el objetivo político de la liberación nacional estaba al servicio de la salvación religiosa. Arana entendía el autogobierno de Euskadi, no como un fin en sí mismo, sino como un medio para llevar a cabo la auténtica misión nacional consistente en mantener la pureza moral y católica del pueblo vasco. Según Sabino, había que separarse del pueblo español, que consideraba inmoral e irreligioso, para preservar el catolicismo de los vascos y la pureza de sus costumbres, lo que permitiría alcanzar la redención religiosa. Resumió esa estrechísima relación entre religión y nacionalismo en el lema «Guztija Erriarentzako ta Errija Jaungoikuarentzako» («Todo para el Pueblo y el Pueblo para Dios»). El propósito político del nacionalismo aranista, condensado en el lema Jaungoikua eta Lagizarra (Dios y Ley Vieja), era la construcción de un ente político vasco basado en la tradición y en la subordinación a las normas y a la moral católicas ${ }^{6}$. Tras la muerte de Sabino Arana, Engracio Aranzadi (Kizkitza), el principal ideólogo del PNV durante el primer tercio del siglo XX, desarrolló las ideas de ese nacionalismo religioso esbozadas por Arana. Aranzadi confirmó la idea sabiniana de supremacía de lo religioso sobre lo político. Entendía las naciones, incluida la vasca, como obra divina. De ahí concluía que la disolución de la identidad nacional vasca era un pecado contra Dios. Por eso la misión del nacionalismo vasco consistía en «salvar al pueblo del

\footnotetext{
5 Sobre el concepto de nacionalismo religioso y su aplicación al nacionalismo vasco, vid. Friedland y Moss, 2015, pp. 423-466; Martínez Rueda, 2017, pp. 721-733.

6 Elorza, 2001, pp. 179-189. Elorza, 2005, pp. 152-153. Corcuera, 2001, pp. 353-441. Granja, 2015, pp. 25-100. Santiago, 2005, pp. 391-400.
} 
que quiso Dios que formáramos parte, salvarlo de la disolución nacional y salvarlo de la impiedad latina» ${ }^{7}$.

Junto a este carácter religioso, otra característica fundamental del nacionalismo aranista fue su sentido agónico de la identidad vasca. Enfrentado a un acelerado y traumático proceso de modernización capitalista y cambio social, Arana situó el espíritu vasco en un sublimado mundo rural tradicional en franco retroceso. Esa civilización rural que había albergado la raza vasca, el euskera, la fe católica, las instituciones tradicionales y un comportamiento virtuoso estaba en decadencia, amenazada por la modernización que Sabino identificaba con la «invasión maqueta». Esa concepción agónica del ser vasco fue heredada por los seguidores de Arana. $\mathrm{Si}$ a fines del XIX el padre del nacionalismo vasco afirmaba que en caso de continuar «la invasión española» la identidad vasca «se va», Engracio Aranzadi sostenía en 1917 que la personalidad nacional estaba «en trance de muerte» ${ }^{8}$.

Esa mezcla de patriotismo religioso y concepción agónica de la identidad creó las condiciones para que el componente sacrificial arraigase profundamente en el nacionalismo vasco. Al impregnar de religiosidad el pensamiento nacionalista, el patriotismo se confundió con la creencia católica, de forma que el militante-creyente se sentía llamado al sacrificio por la fe y por la patria a la vez. La intensidad de la unión entre salvación religiosa y nacional conducía a la exaltación como mártires de aquellos abertzales dispuestos a entregarlo todo por la patria ${ }^{9}$. No es de extrañar, pues, que la figura del sacrificio-martirio por Euskadi y por Dios esté muy presente desde el primer momento en el nacionalismo aranista. Quien entregara su vida por Euskadi no sería sólo un héroe nacional, sería también un mártir religioso, según se desprende de las palabras de Sabino Arana:

«Morir por la patria $[\ldots]$ no es morir por causa mundana, sino morir por Dios, Fin último de todas las cosas.

Dios, por consiguiente, Supremo Juez e infinitamente justo, sabrá premiar según su Misericordia a quien por su Patria [...] viva sufriendo o pierda la vida.

\footnotetext{
7 Sobre el pensamiento de Kizkitza véase el «Estudio preliminar» de Luis Castells del libro de Aranzadi, 2015, 9-86, de donde está tomada la cita.

${ }^{8}$ Granja, 2015,pp. 55. Castells, 2015, p. 44.

${ }^{9}$ Linz, 2006, pp. 11-36. Elorza, 2005, pp. 60.
} 
El patriota, el verdadero patriota [...] vivirá y morirá, viviendo vida de sacrificios y ofreciéndose a la muerte si las circunstancias a los sacrificios y a la muerte le conducen, sin jamás exigir de sus compatriotas el más pequeño agradecimiento por sus sacrificios y sus obras.» ${ }^{10}$

La llamada al sacrificio por la patria caracterizó, pues, al nacionalismo vasco desde sus orígenes. Arana lo expresó de diversas maneras con su vehemente estilo. Proclamó su disposición personal a entregar su vida por la salvación de su patria. Escribió poemas como Lenago il (Antes morir, 1895) o Kantauritarrak (Los cántabros,1888) en los que exaltaba la muerte gloriosa en defensa de Dios y de los fueros. Mitificó y manipuló la historia en busca de héroes nacionales que habrían dado su vida en defensa de la patria vasca. En su libro Bizkaya por su independencia (1892) narró de manera idealizada cuatro batallas medievales (Arrigorriaga, Munguía, Ochandiano y Gordejuela) en las que soldados vascos derramaban su sangre por la independencia de la patria. Arana glorificaba esas muertes y las convertía en modelo de conducta: «iDichosos aquellos antepasados nuestros que perdieron su vida por mantener incólume la independencia de Bizkaya! Bien presto daríamos nosotros la nuestra», escribió en Bizkaitarra (30-9-1894). Incluso recurrió a la ficción para glorificar la muerte patriótica mediante la obra de teatro Libe (1903), nombre de una heroína que moría en la batalla de Munguía (1471) exhortando a los soldados vascos a resistir a los invasores españoles ${ }^{11}$.

Tras la muerte de Sabino Arana sus seguidores identificaron su figura con el sacrificio por la patria. Fue presentado como el Maestro, como el Jesucristo nacional entregado en martirio por la salvación de Euskadi. Si Kizkitza le llamó «héroe cristiano de las catacumbas», su correligionario Altolaguirre le calificó de «redentor» muerto en el «calvario» ${ }^{12}$. Su mensaje sacrificial fue continuado por sus discípulos. Uno de ellos, Evangelista de Ibero, sacerdote navarro autor del catecismo nacionalista Ami Vasco, lo expresó con absoluta claridad cuando a la pregunta de qué debe hacer un patriota por la conservación del territorio nacional, respondía que debía «coger las armas y hasta perder la vida, si preciso fuera, para

\footnotetext{
10 S. Arana: «Mártires de la Patria», Baserritarra, n. ${ }^{\circ} 4,23-\mathrm{V}-1897$.

11 Granja, 2015, pp. 53-66. Rubio y De Pablo, 2015, pp. 2-26.

12 Granja, 2015, pp. 335-345.
} 
impedir que caiga a manos del enemigo» ${ }^{13}$. Las tendencias más radicales del nacionalismo acentuaron ese discurso sacrificial. Por ejemplo, en el diario Aberri, portavoz del nacionalismo radical en los años veinte, se repetía y desarrollaba el lema Lenago il (Antes morir) de un viejo poema de Sabino: «iLenago il! ¡Antes morir! ¡Antes perecer que resignarse a la esclavitud!» ${ }^{14}$. Durante la Segunda República el grupo radical de Euzko Mendigoxale Batza, aglutinado en torno al semanario Jagi Jagi, impulsó esa mística del sufrimiento por la patria. Sus seguidores sostenían que solamente mediante el sacrificio y el sufrimiento se lograría la libertad de Euskadi. Repitiendo los tópicos de la narrativa martirial, se proclamaba que la sangre de los hijos de la patria engendraría su redención y se llamaba a los abertzales a imitar la conducta de quienes habían entregado su vida. Tanto los aberrianos en los años veinte como los mendigoixales en los treinta intensificaron y reelaboraron la retórica del sacrificio por la patria, influidos por la rebelión Pascua irlandesa de 1916, mitificada y convertida en ejemplo a seguir ${ }^{15}$. Pero el discurso sacrificial no era exclusivo de las tendencias radicales del nacionalismo, aunque estas lo divulgaran con especial intensidad. Era compartido por el conjunto del nacionalismo vasco. Incluso la corriente laica y liberal, representada por Acción Nacionalista Vasca, recogió en su manifiesto fundacional de 1930 esa cultura martirial patriótica: «Sabemos que nuestro ideal no puede triunfar sin lucha, que es dolor, persecución, sufrimiento, sacrificio y martirio» ${ }^{16}$. Así que en vísperas de la guerra civil la exaltación del sacrificio por la patria era un lugar común en el discurso del nacionalismo vasco, pero al mismo tiempo era un elemento puramente retórico. Si exceptuamos la muerte de algún joven nacionalista en enfrentamientos armados con militantes de izquierda, no se había derramado sangre de abertzales por Euskadi. Al fin y al cabo, los soldados vascos que habían caído luchando por la independencia de Vizcaya no eran más que protagonistas de lejanas leyendas medievales mitificadas por Arana. La heroína Libe no era más que un per-

13 Ibero, 1906, p. 23. El libro está dedicado a la memoria de Sabino Arana, calificado de «mártir de Jaungoikua [Dios] y de Euzkadi».

${ }^{14}$ Citado en Fernández Soldevilla, 2016, p. 36. El poema de Arana Lenago il fue escrito cuando estaba encarcelado en noviembre 1895 y publicado en Baserritarra, n. ${ }^{\circ} 15$ (8 de agosto de 1897).

15 Granja, 2007, pp. 278-279. Fernández Soldevilla, 2016, pp. 71-73. Núñez Seixas, 2012, pp. 547-563

${ }_{16}$ La Tarde, 3-12-1930, p. 5 (disponible en: http://www.liburuklik.euskadi.net/applet/ libros/JPG/bfb3/ BFB_00007/1930_12_03/BFB_00007-1930_12_03.pdf [15-12-2016]). 
sonaje de ficción que nada tenía que ver con la realidad. Hasta el propio Sabino Arana, máximo exponente para el nacionalismo vasco del sacrificio por la patria, había fallecido de muerte natural, víctima de la enfermedad de Addison ${ }^{17}$. Esos héroes y mártires de Euskadi no eran auténticos. Sin embargo, la guerra civil cambió esta situación al unir el discurso martirial con la muerte real, percibida como sacrificio por Euskadi.

\section{La guerra civil: cultura, experiencia y memoria}

La sublevación militar del 18 de julio planteó al PNV, partido católico, el dilema de elegir entre la República o los militares golpistas. En los primeros momentos la actitud de los nacionalistas fue de prudente espera, hasta ver cómo evolucionaban los acontecimientos. El fracaso del golpe y su deriva en guerra civil hizo imposible la neutralidad. Obligado a tomar partido, el PNV se decantó por el bando republicano con la esperanza de conseguir el estatuto de autonomía. Sin embargo, durante los primeros meses de la guerra, el comportamiento de los nacionalistas fue vacilante y poco beligerante, más preocupados por mantener el orden y el culto católico que por combatir en el frente contra los sublevados. Esas dudas se disiparon con la aprobación del estatuto de autonomía y la formación del primer Gobierno Vasco de la historia el 7 de octubre de 1936, un gobierno casi independiente de hecho por la coyuntura bélica, presidido por el carismático líder nacionalista José Antonio Aguirre y compuesto por todas las fuerzas republicanas, izquierdistas y nacionalistas vascas. El autogobierno cambió la actitud del PNV ante la guerra, asumiendo un firme compromiso en la lucha contra los franquistas ${ }^{18}$.

La nueva postura nacionalista fue acompañada de un discurso y de una cultura de guerra capaz de movilizar a sus seguidores para luchar, no por una República española, sino por la patria vasca, en sintonía con la cultura política nacionalista. El nuevo relato de la guerra civil sostenía que se trataba de un conflicto bélico impuesto al País Vasco desde el exterior, una guerra no deseada por el pueblo vasco, al que no quedó otro remedio que defenderse de la agresión externa. Se presentaba la guerra en el

17 Sabino Arana falleció a los 38 años. Sus seguidores han argumentado que contrajo la enfermedad de Addison como consecuencia de su encarcelamiento, aunque, según señala José Luis de la Granja, 2015, p. 342, no existe ninguna prueba que lo demuestre.

${ }_{18}$ De Meer, 1992, pp. 88-151. Granja, 2007, pp. 293-347. De Pablo, 2003, pp. 115-141. 
País Vasco al margen de la guerra civil española en su conjunto, como si fuera un conflicto aislado, en el que los vascos luchaban por Euskadi, por su libertad y por su autogobierno. Este relato encajaba en la visión aranista de la historia vasca, interpretada como una secular agresión de España contra Euskadi, y formaba parte de una específica cultura de guerra elaborada por el nacionalismo vasco durante el conflicto, que se expresaba en los batallones nacionalistas mediante la exhibición de sus propios símbolos (la ikurriña, en lugar de la bandera republicana), sus rituales diferentes (las misas de campaña celebradas por sus propios capellanes abertzales), sus himnos particulares (el Eusko Gudariak), una imagen del enemigo como invasor español, etc. Uno de los elementos fundamentales de esa cultura de guerra era el gudari, soldado vasco que se sacrificaba por Euskadi ${ }^{19}$.

El culto a la figura del gudari caído, símbolo del héroe mártir nacional, se inició durante la guerra. Sus mensajes repetían los tópicos de la narrativa martirial y condensaban en el gudari caído las ideas del sacrificio patriótico del nacionalismo vasco desde sus orígenes. Se presentaba la muerte del soldado vasco como la materialización de un sacrificio glorioso por la salvación de la patria. Se calificaba su muerte como «gloriosa inmolación», necesaria para que la patria perviviera: «Los gudaris, unidos en un solo espíritu, han defendido la patria vasca. ¡Honor a los que cayeron! Ahora podemos repetir junto a vuestra muerte: la ceniza de los muertos es quien crea la patria». La nación vasca sería así redimida por la sangre de sus hijos que generosamente se entregaban por la madre patria. La prensa nacionalista se refería a los gudaris caídos como mártires que debían ser glorificados, como «vidas inmoladas a plena conciencia», cuyo sacrificio no sería estéril. ${ }^{20}$

Esas imágenes, valores e ideas entroncaban con la tradición del nacionalismo aranista que, como hemos visto, ensalzaba el sufrimiento y la entrega absoluta por la patria vasca. Tras las dudas iniciales del verano del 36, el nacionalismo vasco había convertido, en el plano discursivo, la guerra civil en guerra patriótica, lo que le permitió insertar su tradicional retórica sacrificial en una guerra real. La sangre y los mártires por la patria que hasta entonces habían permanecido en un ámbito puramente retó-

19 Sobre el relato nacionalista de la guerra Granja, 2007, pp. 349-367, y sobre esta cultura de guerra Núñez Seixas, 2007, pp. 559-599.

${ }^{20}$ Gudari, n. ${ }^{\circ} 1$ (6-3-1937), n. ${ }^{\circ} 4$ (8-4-1937), n. ${ }^{\circ} 5$ (15-4-1937), n. ${ }^{\circ} 10$ (1-6-1937). Fernández Soldevilla, 2016, p. 151. 
rico se convertían ahora en realidad material, según esa específica cultura de guerra nacionalista. Expresiones como Lenago il (Antes morir) que habían sido título de poemas de Sabino Arana o de artículos de la prensa abertzale, ahora daban nombre a batallones de gudaris que hacían la guerra y morían en el campo de batalla. Con ello no sólo se dotaba de cierta verosimilitud a las ensoñaciones sacrificiales del nacionalismo aranista. Además, el componente martirial alcanzaba una intensidad hasta entonces desconocida al encuadrar a la juventud en defensa de Euskadi y al proporcionar a la nación héroes de carne y hueso caídos por la patria vasca y por Dios frente a la invasión enemiga, según decían las necrológicas del diario Euzkadi. Como señaló el veterano nacionalista Julio de Sarasua en 1986, la guerra provocó en los jóvenes nacionalistas una suerte de «clímax apasionado», pues «la Patria ya no era una difusa entelequia ni una bucólica imagen cromática, sino un SER VIVO, movilizado, en pie galvanizado por un alevoso y doloroso ataque ${ }^{21}$.

En ese concreto momento histórico y en ese específico marco cultural se sitúa nuestro personaje, Joseba Elosegi, en aquella época militante de las juventudes del PNV, quinto hijo de una familia muy numerosa de clase media donostiarra, de convicciones católicas y nacionalistas. Tenía 20 años cuando estalló la guerra civil. Poco antes había sido llamado a quintas, pero, acabado el período de instrucción militar, decidió presentarse como voluntario para incorporarse a las milicias nacionalistas. Poco después ascendió al rango de oficial. Libró sus primeros combates en el verano de 1936 en las proximidades de la localidad guipuzcoana de Asteasu donde, sitiado por fuerzas enemigas, vio por primera vez la muerte de un joven compañero gudari. Elosegi presenció el bombardeo de Durango y fue el militar del Ejército Vasco de mayor graduación -capitán de la compañía Zarragoitia del batallón Saseta - presente en Gernika el 26 de abril de 1937, cuando se produjo el bombardeo que destruyó la villa $^{22}$. Semanas después uno de sus hermanos, también gudari del Ejército Vasco, murió en combate en Vizcaya. Tras la caída de Bilbao en manos franquistas en junio de 1937, Elosegi se rindió a las tropas italianas en el marco del Pacto de Santoña. Como es sabido, las condiciones de ese acuerdo negociado por los dirigentes del PNV al margen del Gobierno republicano no fueron respetadas y los batallones vascos acabaron en ma-

21 Citado en Núñez Seixas, 2007, pp. 572-574.

22 AHE, Fondo oral Blasco Olaechea, entrevista a Joseba Elosegi, s/f. 
nos franquistas. Elosegi fue juzgado por un tribunal militar el 8 de octubre de 1937. Según escribió tiempo después, el fiscal militar le acusó de ser responsable de la destrucción de Gernika, según la versión franquista que acusaba a los «rojo-separatistas» de la devastación de la villa. Fue condenado a pena de muerte. Sin embargo, el 19 de enero de 1938 fue canjeado por un preso derechista. Junto a otros cuarenta prisioneros liberados fue conducido a Cataluña donde se incorporó al ejército republicano y combatió en el frente hasta el final de la guerra, que concluyó con el grado de teniente coronel $^{23}$.

El caso de la familia Elosegi es buen ejemplo del carácter fratricida que tuvo la guerra civil, también en el País Vasco. Además de Joseba, cuatro de sus hermanos combatieron en la guerra, dos en el bando republicano y otros dos en el franquista. El mayor de ellos, «hombre honrado, religioso, de derechas y receloso de los rojos», alcanzó el grado de Teniente de artillería adscrito a las Flechas Negras italianas. Según relató Joseba Elosegui, su hermano mayor le propuso liberarle a condición de que se alistara en una unidad de Flechas Negras, lo que él rechazó. Otro de sus hermanos, de nombre Iñaki, gudari del Ejército Vasco, murió combatiendo en el monte Jata (Vizcaya), mientras el cuarto de los hermanos, llamado José Manuel, disparaba desde el bando franquista ${ }^{24}$. Paradójicamente, esa experiencia de trágica división apenas tuvo reflejo en la memoria de la guerra de Joseba Elosegi.

La experiencia bélica fue un fenómeno de larga duración que no se agotó con el fin del conflicto. Por el contrario, impregnó el imaginario del nacionalismo vasco del futuro y continuó influyendo en Joseba Elosegi durante toda su vida a través de la memoria. Durante el franquismo el nacionalismo vasco elaboró una memoria que mitificaba la experiencia de guerra. En lugar del horror del conflicto, se evocaba el sacrificio por la patria, se recordaba la guerra como un acontecimiento heroico. Un autor y político tan influyente primero en el PNV y luego en el nacionalismo radical como Telesforo Monzón llegó a calificarla de «guerra de ángeles» o de «sublime locura colectiva» ${ }^{25}$. Esta memoria de guerra se basaba en dos ideas fundamentales. En primer lugar, dando continuidad al relato construido en el 36 , se consideraba la guerra no como un conflicto civil, sino como una guerra en defensa de Euskadi, víctima de una

23 Elosegi, 1971,pp. 143-271.

${ }^{24}$ Elosegi, 1971, pp. 235-237. AN, EGI Venezuela, 344-14.

25 Martínez Rueda, 2016, 267-297. 
agresión externa que pretendía destruir la identidad y el autogobierno vascos, un episodio más de la lucha secular contra España, en defensa de la libertad vasca. Esa agresión contra el pueblo vasco habría sido resistida heroicamente por el gudari, cuya glorificación y culto constituían el otro elemento central de la memoria de guerra nacionalista. En la prensa nacionalista del exilio, a través de testimonios de veteranos o en la literatura abertzale el gudari era idealizado como el soldado vasco por excelencia, generoso, valiente y pacífico, encarnación del héroe vasco dispuesto a entregar su vida por Euskadi. ${ }^{26}$

Unos treinta años después de acabada la guerra civil Joseba Elosegi escribió sus memorias de guerra. Lo hizo poco antes de tratar de inmolarse, por lo que esos textos deben ser leídos como parte de su testamento político, cuya finalidad era denunciar el franquismo y revitalizar a la oposición abertzale ${ }^{27}$. Su relato del pasado coincidía en lo sustancial con la memoria de guerra nacionalista y mostraba una enorme distancia con la visión crecientemente dominante en la España de los sesenta que recordaba la guerra civil como contienda fratricida que debía ser superada mediante una auténtica reconciliación nacional ${ }^{28}$. Las memorias de Elosegi son un buen ejemplo de lo que George L. Mosse (1990) denominó mitificación de la experiencia de guerra para referirse a una visión idealizada que evocaba la gloria de combatir por la nación y que recordaba la guerra como un acontecimiento patriótico pleno de significado. Elosegi se refería a la guerra civil como un episodio que tuvo la virtud de presentar a los vascos ante el mundo «como Pueblo, con un sentimiento nacional definido, una filosofía de la vida propia y una conducta humana ejemplar». Fue un acontecimiento útil porque valió para «despertar la conciencia vasca», según sus palabras (1971: 323). Por eso recordaba con orgullo su participación y la de sus compañeros gudaris voluntarios en la guerra.

${ }^{26}$ Fernández Soldevilla, 2016, pp. 150-163. Mees, 2015, pp. 51-69. Rubio Caballero, 2014, pp. 135-155. Aguilar, 1998, pp. 121-154.

27 Tras decidir inmolarse a lo bonzo ante Franco, Elosegi escribió un diario de los días previos a su acción. Entregó ese texto, junto a sus memorias de guerra, a Telesforo Monzón para que se encargara de su publicación tras su inmolación. Fondo Irujo, Cartas de T. Monzón a M. Irujo, fechadas el 28 de marzo de 1971 (disponible en: http://www.euskomedia. org/PDFFondo/irujo/4799.pdf) y 1972 (disponible en: http://www.euskomedia.org/ PDFFondo/irujo/6947.pdf) [Consulta:15-12-2016].

28 Juliá, 2004, pp. 437-462. Aguilar, 2008, pp. 173-187. Bernecker y Brinkmann, 2009, pp. 208-211. Richards, 2014, pp. 197-224. 
Evocaba la generosidad y entusiasmo del joven gudari para luchar por una causa justa:

«El gudari voluntario se lanzó a la guerra con entusiasmo para luchar y la mejor disposición para ser útil. Considerándose siempre hombre libre y convencido de que su presencia en el frente obedecía solamente a su deseo espontáneo de defender una causa justa.» ${ }^{29}$

La causa justa a la que se refería Elosegi era la defensa de Euskadi, víctima de una agresión externa, repitiendo la vieja idea de la guerra civil como guerra patriótica. Ante un ataque que buscaba la destrucción de su identidad, los vascos tuvieron que responder: «aquella guerra impuesta desde fuera en reto tiránico y amenazador, y aceptada por los vascos por imperativos de legítima defensa $»^{30}$.

La mitificación de la experiencia bélica de Elosegi no ocultaba el horror del conflicto, pero en lugar de atribuirlo a la propia naturaleza de la guerra, lo imputaba exclusivamente al bando franquista. En una visión dicotómica contraponía el bien, encarnado en la figura del gudari, al mal, identificado con el bando franquista, que alcanzó su máxima expresión en la destrucción de Gernika. Su recuerdo de este acontecimiento aunaba dos denuncias: la muerte y el sufrimiento provocados por el bombardeo sobre una indefensa población civil y el ataque simbólico contra el pueblo vasco al destruir «la villa santa de los vascos», su capital moral y política. Según escribió en Quiero morir por algo (1971: 150), al sacar de los escombros el cuerpo ensangrentado y sin vida de un niño de tres años, ante la mirada desgarradora de su madre, juró «abrasar con fuego la conciencia de los responsables» de aquella barbarie. Frente a esa crueldad, Elosegi divulgaba la idea del gudari pacífico - difundida también en la prensa nacionalista y en los escritos de Telesforo Monzón - que hacía la guerra de una forma noble, expresión de la idiosincrasia del pueblo vasco. Según este relato, el gudari no se comportaba como los milicianos foráneos que cometían desmanes, abusos y violaciones. Por el contrario, era un soldado pacífico, generoso y no violento: «No existía odio en nuestra acción. No habíamos deseado la guerra; no queríamos matar y destruir (...). No sabíamos hacer daño y no queríamos perjuicio para quien no tuviera culpa». En lugar de atacar, el gudari se defendía de un enemigo que buscaba su

\footnotetext{
${ }^{29}$ Elosegi, 1971, p. 65.

30 Elosegi, 1971, p. 144.
} 
muerte y la del pueblo vasco. El propio Elosegi se presentaba a sí mismo como ejemplo de ese modo virtuoso de conducta cuando evitó el linchamiento de un piloto alemán que había participado días antes en el bombardeo de Gernika. Y es que, según sus palabras, el gudari «no era capaz de tomarse la justicia por su mano» ${ }^{31}$.

La mitificación de la experiencia de guerra se aprecia también en la forma en que Elosegi recordaba las relaciones entre los soldados y la organización del ejército vasco. En lugar de una rígida disciplina militar, en la tropa de gudaris reinaba la alegría, el optimismo y la camaradería. Sus mandos eran valientes, prudentes y llamados por el grupo: «todos éramos amigos y el oficial uno más». Un ejército democrático y de una valentía extraordinaria: «a nosotros los gudaris no nos asustaba nada, la verdad», declaró en los años ochenta. Y también un ejército del pueblo, que a su paso era saludado por los campesinos: «Todos éramos el mismo Pueblo, empeñados en defender nuestras vidas, nuestra libertad $»^{32}$. Nada tenía que ver ese ejército idealizado con el republicano en el que, según Elosegi, reinaba una severa disciplina. Combatió en ese ejército en el frente de Cataluña durante un año, tras ser canjeado a inicios del 1938. Pero frente a la mitificación de la experiencia de guerra en el País Vasco, recordaba esta etapa como un tiempo desgraciado, que pasó terriblemente mal y que prefería olvidar.

Elemento esencial de la glorificación del soldado vasco era su disposición al sacrificio supremo. Elósegi presentaba al gudari dispuesto «a luchar hasta perder la vida si fuera preciso». Recordaba que, creyendo estar próximo a morir durante el bombardeo de Gernika, consideraba «un honor ser enterrado en el pueblo venerado por los vascos». Cuando el gudari caía en combate, su muerte era recibida por el grupo como un sacrificio patriótico, que se honraba cantando «el himno de los vascos». La glorificación de esa conducta de sacrificio por la patria hacía de ella un modelo a imitar por las nuevas generaciones, convocadas por Elosegi a continuar «la lucha» y a «darlo todo» por Euskadi: «Mantente siempre en la brecha, joven amigo, y ofrece cada día tu ejemplo. Tu lucha de hoy es continuación de nuestra guerra de ayer» ${ }^{33}$. La exaltación del sacrificio y muerte

${ }^{31}$ Elosegi, 1971, pp. 57-58 y 159.

32 Elosegi, 1971, pp. 63 y 71. AHE, Fondo Oral Blasco Olaechea, entrevista a Joseba Elosegi, s/f. Sobre la idealización de las relaciones de camaradería en la guerra vid. Mosse, 2016, pp. 54-57; Kühne, 2016; Lafon, 2014.

33 Elosegi, 1971, pp. 153, 203, 326-327. 
por la patria, muy presente desde su origen en el nacionalismo vasco, intensificada durante la guerra civil, se mantenía en la memoria y a través de ella se trasmitía a las nuevas generaciones treinta años después de acabado aquel conflicto bélico.

\section{Quiero morir por algo: la autoinmolación por la patria}

Acabada la guerra civil Joseba Elosegi se exiló en Francia. A inicios de los años cuarenta empezó a colaborar con los servicios de información del Gobierno Vasco en el exilio. Bajo el pseudónimo de Félix se encargó de contactar y colaborar con la resistencia del interior y de trasladar personas y documentación diversa (propaganda, informes, publicaciones, etc.) por la frontera hispano-francesa. Esta actividad le llevó a pasar temporadas en San Sebastián, donde residía clandestinamente utilizando el nombre y la documentación de su hermano José Manuel, excombatiente franquista. Al acabar la Segunda Guerra Mundial con la derrota del fascismo, las expectativas de derrocamiento del franquismo se dispararon y se intensificó la actividad antifranquista. En esa época se pensó en él para participar en comandos armados instalados en el País Vasco peninsular, que finalmente no llegaron actuar. En ese contexto de enorme optimismo y revitalización de la resistencia antifranquista, Elosegi, hombre de acción amante del riesgo, decidió realizar una operación espectacular, un acto simbólico que tuviera repercusión pública. En julio de 1946 en vísperas de la conmemoración del «Alzamiento Nacional» subió por la noche a lo más alto de la catedral de San Sebastián e izó allí una ikurriña. Fue descubierto, detenido y condenado a seis meses por esa acción. Se exiló de nuevo en Francia. Allí se casó en 1948, formó una familia y continuó militando en la resistencia antifranquista del nacionalismo vasco ${ }^{34}$.

Las enormes expectativas de la oposición de mediados de los años cuarenta se convirtieron en frustración en los cincuenta ante la consolidación del régimen franquista. La estrategia del Lehendakari Agirre y del nacionalismo vasco, que habían puesto todas sus esperanzas en una intervención aliada, fracasó estrepitosamente. La resistencia y el activismo político del PNV fueron languideciendo progresivamente. La

34 AN, Rezola 136-6; EBB 380-1, 10-7. Elosegi, 1971, pp. 302-305. 
muerte del Lehendakari Aguirre en 1960 intensificó esa sensación de fracaso y desánimo en el seno de la oposición peneuvista ${ }^{35}$. Para entonces se había manifestado ya una profunda contradicción en el nacionalismo vasco. El discurso de lucha constante y sacrificio absoluto por la patria sembrado por Arana, materializado durante la guerra civil y trasmitido a las nuevas generaciones nacionalistas contrastaba con la pasividad del PNV. El mito del gudari, divulgado mediante la memoria nacionalista de la guerra, distaba enormemente de la inacción del PNV. En 1959 un grupo de jóvenes nacionalistas rompieron con la dirección del PNV, fundaron ETA y se consideraron herederos de la idea de sacrificio y entrega absoluta por la patria. Como dijo Mario Onaindía: «Por una parte se nos transmitía en el círculo familiar una leyenda heroica de la guerra [...]. Pero, al mismo tiempo, [...] [los miembros de la generación anterior, la generación de los gudaris] no movían un dedo contra la dictadura. Nos fuimos de casa para continuar su guerra». Los jóvenes etarras se declararon continuadores de los gudaris del 36, dispuestos a morir por Euskadi ${ }^{36}$. Adaptaron el componente sacrificial del nacionalismo - que tradicionalmente había identificado la entrega a Dios y a la patria - a los profundos cambios religiosos y culturales de los sesenta. En un contexto de acelerada secularización pasaron de adorar a Dios a venerar a la patria, creando una nueva religión política ${ }^{37}$ que aspiraba a sustituir al tradicional nacionalismo religioso. El resultado fue que entre la juventud del nacionalismo radical, aglutinado en torno a ETA, reverdeció el mensaje sacrificial y arraigó una especie voluntad de martirio secular por la patria sacralizada. Había que entregar la vida por Euskadi, como reflejan estas palabras de Mario Onaindía en referencia a los militantes de ETA de finales de los años sesenta: «En fin, todos, empezando por Txabi [Etxebarrieta, primer muerto de ETA en enfrentamiento con la policía] queríamos inmolarnos, y no porque el pueblo vasco lo mereciera, sino precisamente porque no lo merecía» ${ }^{38}$.

En ese momento histórico de languidecimiento de la oposición peneuvista y en ese marco cultural de resurgimiento y adaptación del mensaje sacrificial abertzale se sitúa la decisión de Joseba Elosegi de inmolarse ante Franco como forma de protesta. Tras largos años de activismo

\footnotetext{
35 De Pablo et alii, 2001, pp. 143-250.

${ }^{36}$ Casquete, 2009, pp. 146-147. Fernández Soldevilla, 2016, pp. 39, 160 y ss.

37 Sáez de la Fuente, 2002, pp. 125-228. Casquete, 2009, pp. 65-76.

38 Citado en Aranzadi, Juaristi y Unzueta, 1994, pp. 192.
} 
político en el exilio Elosegi había regresado a San Sebastián en 1964. Su labor durante tanto tiempo en la resistencia antifranquista no había dado resultado alguno, mientras su organización política estaba sumida en el desánimo y la pasividad. A pesar del sentimiento de frustración dominante, Elosegi no renunció a su espíritu de rebeldía, ni a su activismo contra el régimen. Afirmaba con orgullo que tras las calamidades padecidas en el amargo exilio le quedaba la virtud «de ser siempre consecuente, de ser en todo momento el que fui» ${ }^{39}$. Mantenía su tendencia al riesgo y a las acciones espectaculares, a pesar de la pasividad del PNV, su partido de toda la vida. Como evidenciaban sus memorias de guerra, conservaba la cultura sacrificial del nacionalismo vasco en la que había sido socializado como joven gudari desde los 20 años. Participaba de aquella «pulsión de muerte» por la patria, compartida por los etarras de los sesenta, que expresó en el título de su testamento político: Quiero morir por algo ${ }^{40}$. En 1970 realizó un espectacular acto de protesta contra el régimen franquista al tratar de inmolarse quemándose a lo bonzo en presencia de Franco durante la inauguración del campeonato mundial de pelota en el frontón Anoeta. Poco después de las siete de la tarde del 18 de septiembre roció sus ropas con alcohol, pasó al primer piso de las localidades del frontón, se acercó a la barandilla, se prendió fuego y al grito de «iGora Euskadi askatatuta!» se lanzó al vacío envuelto en llamas. El golpe fue amortiguado al caer sobre un inspector de policía y las llamas fueron sofocadas por un agente que portaba un extintor ${ }^{41}$.

Esta acción se inspiraba en el tradicional discurso sacrificial del nacionalismo vasco. Elosegi mantenía la visión agónica de la nación vasca formulada por Sabino a finales del XIX. Creía que la supervivencia del pueblo vasco, «uno de las más viejos de la tierra», estaba seriamente amenazada por el franquismo y por la masiva inmigración que conducía a la españolización de la identidad vasca. Para evitar la desaparición del pueblo vasco proponía la «lucha sin descanso», el «sacrificio» y hasta la muerte si fuera necesario: «No quiero que camine hacia la muerte mi causa. Hay que revitalizarla, hay que luchar por ella y, si es preciso, hay que morir por ella». Consideraba que era su «deber arriesgarlo todo y morir» por la salvación de la patria. Al poner en práctica el sacrificio supremo por la patria amenazada, Elosegi estaba dando continuidad al mensaje sabiniano de

\footnotetext{
39 AN, EBB 30-11, 3-5-1965.

40 Elosegi, 1971, p. 29. Aranzadi, 2001, vol. I, pp. 67-73.

41 AN, EGI Venezuela 344-14.
} 
martirio patriótico, materializado durante la guerra civil y continuado posteriormente a través de la mitificación de la experiencia de guerra. Su acción de autoinmolación era un eslabón más de aquel discurso que exaltaba la muerte por la patria y la vinculaba con la idea de la resurrección nacional. Como es propio del héroe-mártir nacional, Elosegi pretendía obtener una rentabilidad nacional a la muerte. Con su gesto quería denunciar la represión franquista contra el pueblo vasco y aspiraba a revitalizar a la comunidad nacionalista. Puesto que todos hemos de morir, «ipor qué no sacarle un provecho a la muerte?», «¿por qué no vender cara la vida cuando su entrega puede beneficiar a una causa justa?», se preguntaba unos días antes de su inmolación. También buscaba la continuidad de la vida después de la muerte. Según relató en Quiero morir por algo, su fe religiosa fue debilitándose, mientras se afianzó su creencia en la nación como valor absoluto. Por eso, podría hablarse de una transferencia de sacralidad que llevó a Elosegi a ver su muerte por la patria como una forma de alcanzar la vida eterna: "Yo quiero algo después de muerto. Quiero vivir en el recuerdo de los míos. Es una forma de no morir. La muerte es no estar en ninguna parte, pero yo deseo quedar en el corazón de los que piensan como yo. Darles ánimo, fe y esperanza en los destinos de Euzkadi». Aunque no hay referencias a Dios en la justificación de su acción, Elosegi, sin abandonar su fe católica, aplicaba a la patria sacralizada conceptos y figuras religiosas. Se consideraba «predestinado al sacrificio»y, al igual que le ocurrió a Jesucristo, esperaba ser traicionado antes de que el gallo cantase tres veces ${ }^{42}$.

La acción de Elosegi fundía el mensaje preexistente del sacrificio patriótico del nacionalismo vasco con la novedad cultural de la autoinmolación como nueva forma de protesta. Como el propio Elosegi explicó (1971:7), la autoinmolación no se entendía como autodestrucción, sino como sacrificio a favor de una causa justa. Esta práctica había sido iniciada por el monje budista Quang Duc en Vietnam, muerto al quemarse a lo bonzo en 1963 en protesta contra el régimen de Diem. Este tipo de autoinmolación estaba vinculada al auge de la fotografía y de la la televisión en los años sesenta, que permitían la rápida difusión de imágenes. De esta forma el sacrificio individual tenía un impacto dramático y una gran repercusión en una amplia audiencia. Por esa razón Elosegi eligió para desarrollar su acción la inauguración del campeonato mundial de pelota,

${ }^{42}$ Elosegi, 1971, pp. 7-11 y 25. Beriain, 2007, pp. 77-118. 
acontecimiento de gran impacto mediático retransmitido en directo por radio y televisión, y cubierto por numerosos medios de comunicación. Ese modelo de protesta se extendió durante los años sesenta por numerosos países. En 1969 lo practicó el joven checoslovaco Jan Palach para denunciar la ocupación soviética tras la Primavera de Praga. El acontecimiento, ampliamente difundido por la prensa española, produjo una ola de inmolaciones en diversos países europeos, siguiendo su ejemplo. Entre 1963 y 1970 la autoinmolación a lo bonzo se había repetido más de 80 veces en distintas partes del mundo y había entrado a formar parte del variado repertorio de formas de protesta ${ }^{43}$. Elosegi admiraba este tipo de acciones y consideraba que los vascos tenían tantos motivos para expresar su protesta ante el mundo como los checoslovacos invadidos por los soviéticos o los monjes budistas vietnamitas. Con su gesto aspiraba a denunciar internacionalmente la situación del pueblo vasco. La autoinmolación solía ir acompañada de un escrito de denuncia de la injusticia y de explicación de los motivos de la protesta. Por eso escribió Quiero morir por algo, una especie de testamento político, custodiado por Telesforo Monzón, en el que aclaraba el sentido simbólico de su acción. Pretendía que «Franco sintiera aquel fuego que provocó en Gernika para destruir la villa santa de los vascos. Aquel fuego que juraba había sido encendido por nosotros los gudaris para desacreditarnos ante el mundo ${ }^{44}$. Vinculaba así su sacrificio de entonces con su pasado de gudari, responsable del Ejército Vasco en Gernika durante el bombardeo, al tiempo que alimentaba el significado simbólico de la villa foral como lugar que representaba la libertad vasca destruida por Franco ${ }^{45}$.

Es difícil calibrar el impacto que la acción de Elosegi pudo tener en la sociedad vasca y en la dinamización de la oposición antifranquista. Probablemente fue uno más entre los varios acontecimientos de aquella época que contribuyeron a la reactivación de la oposición nacionalista, cuyo auténtico catalizador fue el proceso de Burgos, celebrado tan sólo tres meses después. Los medios de comunicación franquistas trataron de ocultar y distorsionar el hecho. La televisión que retransmitía el evento deportivo evitó enfocar a Elosegi ardiendo, mientras la radio sintonizaba música para acallar el griterío del público. La prensa oficial presentó la autoinmo-

\footnotetext{
43 Biggs, 2005, pp. 173-208.

44 Elosegi, 1971, pp. 24 y 38.

45 Mees, 2012, pp. 407-429.
} 
lación como un «triste incidente» protagonizado por un enajenado mental en estado de embriaguez que intentó suicidarse ${ }^{46}$.

Los medios nacionalistas del exilio alabaron la figura de Elosegi, glorificaron su disposición al sacrificio por la patria y presentaron su acción como un ejemplo de «heroísmo total» que debía convertirse en una llamada a la conciencia nacional de todos los vascos. Se recuperó el tradicional discurso martirial del nacionalismo vasco, adaptándolo al gesto de Elosegi. Aunque no falleció, llegó a escribirse que había dado «su vida para que Euzkadi viva» ${ }^{47}$. El boletín informativo del PNV, Euzkadi, afirmó que Elosegi era militante del partido y miembro activo de la resistencia vasca. Calificó su acción de «espectacular y heroico acto frente a Franco, en simbólico gesto que dramáticamente recuerda al mundo el trágico calvario por el que atraviesa el pueblo vasco» ${ }^{48}$. Gudari, publicación de las juventudes del PNV, sacó un número especial y escribió en su editorial: «[Elosegi] quiere que su sacrificio sirva de ejemplo y de estímulo, y los remisos se levanten y contesten a su llamada». Se publicó una poesía en su homenaje, que sería la letra de una canción compuesta en 1971, ensalzando su voluntad de «morir para el pueblo» («erriarentzat hiltzia»). Se recordó su pasado de gudari y se estableció una línea de continuidad en el sacrificio por la patria entre la guerra civil y el intento de inmolación: «Erakutsi ederra zure lengo ta gaurko bizitza jokatzea Euzkadigaitik» («Hermoso ejemplo el jugarte la vida por Euzkadi ayer y hoy» $)^{49}$. Sectores próximos al nacionalismo radical de ETA calificaron su acción como un «gesto sublime», comparable a la gesta del Ché Guevara, al tiempo que repetían las llamadas de Elosegi a morir por la causa vasca si fuera preciso. Presentaron su acción como nexo que unía la lucha de los gudaris de la guerra civil con la de los militantes de ETA. Un escrito anónimo, probablemente de Telesforo Monzón, sostenía que Elosegi «supo unir la guerra pasada con la lucha presente... los muertos y presos de ayer con los muertos y presos de hoy» ${ }^{50}$. Aunque entre los dirigentes del PNV hubo alguna voz que en privado criticó la acción de Elosegi por su aspecto exótico, oriental,

\footnotetext{
${ }^{46}$ ABC, El Diario Vasco, La Gaceta del Norte, 19-9-1970. The Sunday Times, 5-3-1972.

47 AN, EBB 64-9.

48 Euskadi, n. ${ }^{\circ} 25$ (1970).

49 Gudari, septiembre de 1970, edición especial.

${ }^{50}$ Egi-Batasuna, n. ${ }^{\circ} 4$ (reproducido en Documentos Y, 1979: 31). Fundación Mario Onaindia, MO-69.
} 
alejado de la moral cristiana, la inmensa mayoría de los seguidores del PNV mostraron su admiración ante un gesto percibido como heroico ${ }^{51}$. A inicios de los años setenta, cuando el régimen franquista iniciaba su proceso de crisis terminal, el discurso sacrificial del nacionalismo vasco se mantenía con vigor, como evidenciaron las reacciones y mensajes de la prensa nacionalista con motivo del intento de autoinmolación de Joseba Elosegi.

\section{Un gudari en la transición: combates por la memoria}

Aunque quedó gravemente herido, Joseba Elosegi no murió como consecuencia de su intento de inmolación. Tras su acción quedó sumido en una depresión, consecuencia de las gravísimas quemaduras que sufrió y de su sensación de frustración por continuar vivo. Sintió que había fracasado, ya que su propósito era morir. Sin embargo, con el tiempo superó el desánimo al percibir la repercusión de su acción y la considerable difusión de su testamento político en forma de libro. Creyó que su gesto había sido útil para despertar la conciencia nacional y para dar a conocer «el problema nacional vasco», por lo que se sintió orgulloso de su acción. Tras numerosas operaciones fue recuperándose físicamente. Inicialmente fue ingresado en el hospital provincial de San Sebastián. En febrero de 1971 fue trasladado al hospital penitenciario de Yeserías y de allí a la prisión de Carabanchel en el mes de junio. En febrero de 1972 fue juzgado por el Tribunal de Orden Público (TOP). El fiscal pidió para él 11 años de cárcel acusado de propaganda ilegal y de lesiones a dos policías, causadas fortuitamente al lanzarse al vacío en el frontón Anoeta. Durante el juicio presentó su acción como un acto no violento de protesta por sentirse acusado de la destrucción de Gernika en la guerra civil, según la versión franquista que responsabilizaba a los «rojo-separatistas» del incendio de la vi$1 \mathrm{la}^{52}$. Finalmente fue condenado a 7 años, de los que cumplió poco más de 3. En octubre de 1973 fue excarcelado.

Durante la Transición la figura de Joseba Elosegi cobró relieve político como emblema de la lucha y del sacrificio por la patria. Contribuyó a

51 Fondo Irujo, Carta de M. Irujo a J. Rezola (19-9-1970) y respuesta de éste (30-91970), J 12 P-Q-R (disponible en http://www.euskomedia.org/PDFFondo/irujo/10525.pdf [15-12-2016]).

52 AN, EGI Venezuela, 344-11.

Historia Contemporánea 56: 187-220 
ello la reedición de sus memorias de gudari, junto a la explicación de su intento de inmolación en el libro Quiero morir por algo, que alcanzó notable difusión ${ }^{53}$. Recuperó su activismo político. Participó en la creación de la primera comisión pro-amnistía de Guipúzcoa a inicios de 1976. Militante del PNV, formó parte de las candidaturas de este partido en las sucesivas elecciones a Cortes Generales. En las primeras elecciones celebradas tras la muerte de Franco en 1977 ocupó el cuarto lugar en la lista al Congreso y no resultó elegido. Sí lo fue en las tres siguientes elecciones a la cámara alta, por lo que fue senador durante 10 años, entre 1979 y 1989. Tras la escisión del PNV en 1986, Elosegi pasó a militar en Eusko Alkartasuna (EA), formación por la que también fue candidato al Senado en 1989, aunque en esta ocasión no obtuvo el escaño.

Durante ese tiempo Joseba Elosegi no fue un político al uso, ni se comportó como un senador típico. Su presencia pública y su protagonismo político eran consecuencia de su actuación en el pasado, ya fuera como gudari durante la guerra civil, como miembro de la resistencia vasca en la posguerra o como héroe nacional dispuesto a la autoinmolación en el tardofranquismo. Su trayectoria le había convertido en símbolo del gudari para el nacionalismo jeltzale, en emblema de la lucha y de la entrega absoluta por la patria. Esta condición de símbolo del sacrificio patriótico dio valor a su figura política en un momento en el que el nacionalismo radical trataba de patrimonializar el discurso martirial del nacionalismo vasco y el legado del gudarismo. Como hemos visto, los militantes de ETA se habían presentado desde el nacimiento de la organización como los nuevos gudaris que tomaban el relevo y continuaban el camino iniciado por los viejos gudaris del $36^{54}$. Recogían la memoria de guerra nacionalista que interpretaba la guerra civil como un episodio más del enfrentamiento entre España y Euskadi, pero la adaptaban a su estrategia violenta al proclamar que la guerra no había acabado y que ETA continuaba el viejo combate del pueblo vasco por su soberanía. El portavoz más significado de ese discurso era Telesforo Monzón, figura histórica del PNV, próximo a ETA desde finales de los sesenta, que había sido el albacea del testamento político de Joseba Elosegi en 1970 y que, según confesó, sintió una profunda emoción cuando éste le comunicó su

53 El País, 20-2-1977. Agotada la primera edición publicada en Francia en 1971 con una tirada de 7.000 ejemplares, la reedición de 1977 puso a la venta 15.000 ejemplares que poco tiempo después estaban a punto de agotarse.

54 Casquete, 2009, pp. 146-147. Fernández Soldevilla, 2016, pp. 160 y ss. 
voluntad de inmolarse ${ }^{55}$. Para neutralizar este discurso y la carismática figura de Monzón el nacionalismo moderado recurrió a militantes como Elosegi que aunaban su pasado de sacrificio patriótico con el rechazo al terrorismo de ETA y el apoyo a la estrategia autonomista del PNV. No es que el nacionalismo jeltzale renunciara a la narrativa martirial que le había caracterizado desde sus orígenes. Simplemente trataba de evitar que el nacionalismo radical la patrimonializase y pusiese el legado simbólico del gudarismo al servicio de ETA.

En ese contexto de combate por la memoria entre el nacionalismo moderado y el radical adquirió notable protagonismo la figura de Elosegi como símbolo del gudari para los seguidores peneuvistas. Desde 1977 su presencia y discurso era habitual en el Gudari Eguna (día del Gudari) que el PNV celebraba anualmente en fecha diferente que el nacionalismo radical ${ }^{56}$. Sus mensajes de esa época compartían con el nacionalismo radical el discurso sacrificial y la exaltación del combate por Euskadi, característicos del nacionalismo desde Sabino Arana. Sus escritos recordaban una y otra vez la entrega total y el sacrificio por la patria, simbolizado en su propia figura y en la de los gudaris caídos: «el hombre que hace cuarenta años era joven luchó heroicamente hasta el límite de sus fuerzas, sufrió lo indecible, resistió (...); aquel hombre luchó entonces y sigue luchando por Euzkadi» ${ }^{57}$. Seguía recordando la guerra civil como guerra patriótica en la que los vascos lucharon «hasta el agotamiento de nuestras fuerzas» a favor de la ikurriña, una bandera que «nos pedía sacrificio, entrega total y aceptación de la muerte si fuera preciso» ${ }^{58}$. También compartía con el nacionalismo radical la idea de la guerra civil como un episodio más de la lucha de Euskadi por la soberanía, una lucha que no había acabado: «nuestra lucha no tendrá fin hasta que los vascos hayamos conseguido aquella libertad que Sabino Arana fue el primero en soñar» ${ }^{59}$. Esa concepción de la política como lucha, como combate por Euskadi le llevó a plantear, nada menos que en el Senado y en los años de plomo del terrorismo etarra, la posibilidad de vol-

55 Martínez Rueda, 2016, 269-299. Fondo Irujo, J 15 M-N, carta de T. Monzón a M. Irujo, 1972 (disponible en: http://www .euskomedia.org/PDFFondo/irujo/6947.pdf [15-12-2016]).

56 Casquete, 2009, pp. 207-210.

57 «Juventud Vasca», Euzkadi n. . 49, noviembre de 1977.

58 «Nuestra ikurriña», Euzkadi n. ${ }^{\circ}$ 9, 30-1-1977

59 «El Partido», Euzkadi n. ${ }^{\circ}$ 89, 17-8-1978. 
ver «a la clandestinidad para defender de nuevo la libertad de los pueblos» con motivo de la aprobación de la LOAPA, que consideraba una «declaración encubierta de guerra al Estado de las Autonomías y a los derechos históricos ${ }^{60}$. Pero al mismo tiempo que exaltaba la continuidad de la lucha y sacrificio por Euskadi, Elosegi alertaba del «laberinto de ideologías» ajeno a la libertad de Euskadi, del maximalismo y marxismoleninismo de la denominada izquierda abertzale, de su exigencia de objetivos utópicos. Se trataba, en suma, de reivindicar para el nacionalismo moderado el legado sacrificial del gudarismo del que el nacionalismo radical pretendía apropiarse. Por eso el discurso de Elosegi combinaba la exaltación del sacrificio patriótico con las críticas al nacionalismo radical, alejado de la auténtica lucha por la libertad vasca, equivocado en sus planteamientos maximalistas, cuyo objetivo era imponer una «dictadura roja» ${ }^{61}$.

El combate por la memoria y por el legado sacrificial del gudarismo entre el nacionalismo moderado y el radical se reflejó también en el debate sobre el estatuto de autonomía. Mientras ETA seguía presentándose como continuadora de los gudaris en lucha por la soberanía, el PNV afirmaba que el estatuto recogía por fin los anhelos de tantos soldados vascos que habían dado su vida por la patria. Mientras Telesforo Monzón, convertido ya en líder carismático de Herri Batasuna, proclamaba que muchos gudaris habían derramado su sangre, no por la autonomía, sino por la soberanía de Euskadi, Elosegi escribía que «tantos gudaris dieron heroicamente su vida» por el estatuto del 36, inferior en competencias al de Gernika de 1979. Incluso se publicó un manifiesto a favor del estatuto de Gernika de viejos gudaris, entre los que, por supuesto, figuraba Elosegi, que identificaba «la lucha por la libertad de Euskadi» durante la guerra civil con la defensa del Estatuto de Gernika: «Los gudaris que participamos en la pasada contienda en defensa del Estatuto de 1936 y que representó entonces la lucha por la libertad de Euskadi, nos ratificamos hoy en nuestra postura, reafirmando nuestro propósito de seguir en la misma línea, apoyando con todas nuestras fuerzas el Estatuto de Gernika de $1979{ }^{6}{ }^{2}$.

60 DSS, n. ${ }^{\circ} 171,29-07-1982$.

61 Diario 16, 1-6-1981.

62 Monzón, 1986, vol. 6, pp. 350-351. «El orden público y el Estatuto de Autonomía», Euzkadi, n. ${ }^{\circ}$ 147. Diario Vasco, 23-10-1979. 
Se ha dicho que durante la transición el PNV practicó una memoria de la guerra civil de dos intensidades ${ }^{63}$. Una, dirigida al consumo interno de la militancia abertzale, se caracterizaba por su mitificación de la experiencia de guerra. Idealizaba al gudari y glorificaba el sacrificio por la patria. Es ahí donde la figura de Elosegi cobraba su auténtica dimensión como símbolo de la lucha y entrega absoluta por Euskadi durante la guerra civil y el franquismo. La otra mirada al pasado del PNV era la oficial, la expresada habitualmente por los dirigentes nacionalistas en los foros políticos institucionales. Era mucho más prudente y sintonizaba mejor con los mensajes de reconciliación nacional y estrategia de silencio dominantes durante la transición y los años ochenta. En este ámbito tenía peor acomodo la figura de Elosegi, senador en aquella época. En aquel momento en que se acordó echar al olvido el pasado y no utilizarlo en el debate político llamaba la atención la presencia en el Senado de un gudari, símbolo abertzale de la guerra civil. Aunque se mostró partidario de la reconciliación nacional, Elosegi aspiraba a desempolvar el pasado. Pretendía que se abrieran los archivos militares para se conociera toda la verdad del franquismo. Sin embargo, su actitud en materia de memoria histórica asustaba a los dirigentes jeltzales, partidarios de mantener una actitud prudente, quienes le prohibieron llevar adelante alguna de sus iniciativas ${ }^{64}$. Elosegi se quejaba especialmente de la persistencia de la simbología franquista ya que en este terreno las autoridades públicas continuaron actuando con mucha cautela, incluso tras la victoria electoral socialista de 1982. A juicio de Elosegi, el mensaje de reconciliación nacional era incompatible con la exhibición de símbolos de la dictadura, presentes en numerosos lugares públicos y de forma muy especial en las instituciones militares ${ }^{65}$. Una de sus primeras iniciativas en el Senado, en mayo de 1979, fue una pregunta al gobierno sobre si estaría dispuesto a devolver a Euskadi las ikurriñas exhibidas en museos militares como símbolos de la victoria franquista. En varias ocasiones pidió a diferentes ministros que se suprimieran los símbolos franquistas de los museos del ejército, con escaso resultado ${ }^{66}$. Así que Elosegi, hombre de acción al que gustaban los gestos simbólicos de impacto público, decidió actuar. En junio de 1984 se presentó acompañado de dos fotógrafos en el Museo Militar de Madrid y se apoderó de

\footnotetext{
63 Rubio, 2014, pp. 135-144.

${ }^{64}$ AHE, Fondo Oral Blasco Olaechea, entrevista a Joseba Elosegi, s/f.

65 Aguilar, 2008, pp. 310-315; Bernecker y Brinkamann, 2009, pp. 225-230.

${ }^{66}$ DSS, n. ${ }^{\circ} 25,21-6-1982 ;$ n. $^{\circ} 45,8-2-1982$.
} 
una ikurriña perteneciente al batallón Itxarkundia del Ejército Vasco, exhibida como trofeo de guerra. El asunto generó cierta polémica. El PNV hizo público un comunicado en el que afirmaba que lo ocurrido había sido una iniciativa particular del senador. El fiscal general se querelló contra Elosegi, quien se negó a devolver la ikurriña y, orgulloso de su acción, declaró que volvería a sustraerla. Aunque se especuló que la bandera podía ser exhibida en el Gudari Eguna, lo cierto es que no volvió a aparecer hasta su muerte ${ }^{67}$.

Joseba Elosegi falleció el 6 de noviembre de 1990, a los 74 años de edad. A su muerte su figura fue reconocida como un símbolo de la lucha y del sacrificio por la patria por todas las corrientes del nacionalismo vasco. Recibió el elogio unánime de los máximos dirigentes de los dos partidos políticos en los que había militado, el PNV y EA. Incluso Herri Batasuna destacó su trayectoria política «en defensa de nuestra soberanía nacional». El diario Deia lo calificó como «uno de los símbolos más carismáticos del abertzalismo». Las esquelas lo titulaban como «Capitán del Batallón de Gudaris Saseta». Su féretro fue cubierto por dos ikurriñas, una perteneciente al batallón en el que había combatido durante la guerra civil. La otra era la famosa bandera sustraída por él mismo en $1984^{68}$. Envuelto en aquellas ikurriñas históricas se le despidió cantando el himno del soldado vasco (Eusko Gudariak) que proclama la disposición del gudari a derramar su sangre por Euskadi. Convertido en símbolo del gudari y del sacrificio por Euskadi, la figura de Elosegi pasó a formar parte del imaginario nacionalista vasco. Por eso, años después de su muerte ha seguido siendo objeto de atención, tema de artículos periodísticos que lo recuerdan o de reportajes emitidos por la televisión autonómica que lo presentan como ejemplo de la rebeldía vasca ${ }^{69}$.

\section{Conclusiones}

La idea religiosa del sacrificio por la patria, común a todos los nacionalismos, arraigó con especial intensidad en el nacionalismo vasco desde sus orígenes. Contribuyó a ello la inicial formulación religiosa del patriotismo vasco que concebía la liberación nacional como un medio para

\footnotetext{
${ }^{67}$ El País, 9 y 10-6-1984. ABC, 8 al 10-6-1984; 17-7-1985; 5-9-1985. Deia, 8-6-1984.

${ }^{68}$ Deia, 6 y 7-11-1990

69 Deia, 1-5-2014. Diario Vasco, 14-3-2006.
} 
la salvación religiosa. Sabino Arana, al fundir nacionalismo y religión, ensalzó la entrega de la vida por la patria y la identificó con el martirio por la fe. Además, el sentido agónico de la identidad vasca, en trance de desaparición según Arana y sus seguidores, hizo que se exaltara el sacrificio supremo por una patria agonizante, necesitada para su resurrección de la sangre de sus hijos. Ese discurso sacrificial fue continuado por los sucesores de Arana durante el primer tercio del siglo Xx. Aunque los sectores más radicales lo difundieron con especial entusiasmo, era compartido por todas las tendencias del nacionalismo vasco. Sin embargo, hasta 1936 ese mensaje martirial se mantuvo en el ámbito puramente discursivo. Se exaltaba el sufrimiento y la muerte por la patria mediante legendarias batallas medievales, a través poemas o de personajes de ficción o por medio de la propia figura de Sabino, presentado como mártir de la nación vasca, aunque había fallecido de muerte natural. Pero en realidad ningún personaje histórico abertzale había realmente entregado su vida combatiendo por Euskadi. La guerra civil cambió esa situación, ya que permitió al nacionalismo vasco situar el tradicional mensaje sacrificial en un nuevo contexto: una guerra de verdad, presentada por la cultura bélica nacionalista como un combate por Euskadi, como una guerra patriótica. Las ensoñaciones sacrificiales que habían caracterizado al nacionalismo vasco desde sus orígenes tomaron cuerpo en la figura del gudari caído, símbolo del héroe mártir nacional ${ }^{70}$. Al encuadrar militarmente a la juventud abertzale en defensa de Euskadi y al producirse la muerte en combate de numerosos jóvenes soldados, el componente martirial del nacionalismo vasco alcanzó una intensidad y difusión hasta entonces desconocidas.

El caso de Joseba Elosegi muestra la persistencia de esa cultura sacrificial, simbolizada en la figura del gudari que definió la identidad de nuestro protagonista. Desde que se alistó como voluntario en julio de 1936 hasta su muerte en 1990 Elosegi se percibió a sí mismo como gudari. Como tal fue considerado y despedido por la comunidad abertzale. Su vivencia de la guerra entroncó con la tradición sacrificial del nacionalismo vasco. A pesar de que dos de sus hermanos combatieron en el frente franquista, percibió la guerra civil como una lucha en defensa de Euskadi, víctima de una agresión externa. En sintonía con la memoria

${ }^{70}$ Fernández Soldevilla, 2016, pp. 36-39, 149-153. Núñez Seixas, 2007, pp. 559-599. Granja, 2015, pp. 56-65. 
nacionalista del conflicto bélico, trasmitió un recuerdo que mitificaba su experiencia de guerra, evocando la gloria de luchar por Euskadi. Idealizó la figura del gudari al que describió como joven voluntario sacrificado por una causa justa, de valentía sin par, generoso, pacífico, enrolado en un ejército en el que reinaba la camaradería y era admirado por su pueblo. Característica fundamental del gudari era su disposición al sacrificio, su entrega absoluta, preparado para luchar hasta perder la vida si fuera preciso. Elosegi no sólo glorificaba la conducta de sacrificio por la patria del gudari, también hacía de ella un modelo a seguir por las nuevas generaciones, a las que décadas después de la guerra llamaba a continuar la lucha por Euskadi. A través de la memoria y de la mitificación de la experiencia de guerra el mensaje sacrificial del nacionalismo vasco pervivió con intensidad y se trasmitió a las nuevas generaciones abertzales.

Sin embargo, en los años sesenta la continuidad del discurso de lucha y entrega absoluta por la patria contrastaba con el languidecimiento y pasividad del PNV. En ese contexto ETA se presentó como el relevo de los gudaris del 36 y sus militantes proclamaron su disposición a morir (y también a matar) por Euskadi. En aquella época Elosegi continuaba imbuido del mensaje sacrificial, propio del gudari. Se sentía predestinado al sacrificio por Euskadi, a cambio del cual esperaba alcanzar una especie de vida eterna en forma de recuerdo de la comunidad nacional. Aunando la tradición sacrificial del nacionalismo con la autoinmolación por fuego como nueva forma de protesta surgida en los años sesenta, decidió quemarse a lo bonzo ante Franco. Su gesto contribuyó a dar continuidad al mensaje de entrega total por la patria. Los medios nacionalistas del exilio glorificaron su disposición a dar su vida por Euskadi y presentaron su acción como un ejemplo de heroísmo extremo.

El discurso sacrificial del nacionalismo vasco se mantenía con vigor en los años setenta y ochenta del siglo Xx. En esa época el nacionalismo moderado y el radical pugnaban por el legado del gudari, símbolo del sacrificio por la patria. Si ETA proclamaba que sus militantes eran «los gudaris de hoy», el PNV recurría a los viejos gudaris como Elosegi, que unían su trayectoria de sacrificio por la patria con el rechazo al terrorismo y el apoyo a la estrategia autonomista. Ambas tendencias continuaban reivindicando el mensaje sacrificial, aunque con diferente intensidad y significado. Si a Elosegi la idea del sacrificio por la patria le había llevado a inmolarse ante Franco como gesto de protesta, los etarras convirtieron la disposición a entregar la vida por la patria en voluntad de matar al su- 
puesto enemigo de Euskadi. Como señala Juan Aranzadi (2001: 69), nadie se siente más legitimado para matar por una causa que quien está dispuesto a morir por ella. Esa línea que separa la disposición a morir por la patria de la voluntad de matar por ella es la que no cruzó Joseba Elosegi y la que estableció una enorme distancia entre su concepción del sacrificio por la patria y la de ETA, aunque ambos compartían la intensa y persistente cultura sacrificial que caracterizó al nacionalismo vasco desde sus orígenes.

\section{Fuentes}

AHE: Archivo Histórico de Euskadi.

AN: Archivo del Nacionalismo.

DSS: Diario de Sesiones del Senado.

Fondo Irujo (Eusko Ikaskuntza - Sociedad de Estudios Vascos).

Fundación Mario Onaindía.

\section{Bibliografía}

AGUILAR, Paloma, «La Guerra Civil española en el discurso nacionalista vasco. Memorias peculiares, lecciones diferentes», en UGARTE, Javier (ed.), $\mathrm{La}$ transición en el País Vasco y España: historia y memoria, UPV/EHU, Bilbao, 1998, pp. 121-154.

AGUILAR, Paloma, Políticas de la memoria y memorias de la política, Alianza, Madrid, 2008.

ANDERSON, Benedict, Comunidades imaginadas. Reflexiones sobre el origen y difusión del nacionalismo. FCE, México, 1993.

ARANZADI, Juan, JUARISTI, Jon y UNZUETA, Patxo, Auto de Terminación, El País, Madrid, 1994.

ARANZADI, Juan, El escudo de Arquiloco, A. Machado Libros, Madrid, 2001.

BERIAIN, José, «Las máscaras de la violencia colectiva: chivo expiatorio-mártir, héroe nacional y suicida-bomba», Sociológica, 64, 2007, 77-118.

BERNECKER, W.L. y BRINKMANN, S., Memorias divididas. Guerra Civil y franquismo en la sociedad y política españolas (1936-2008), Abada Editores, Madrid, 2009.

BIGGS, M., «Dying without killing: Self-inmolations, 1963-2002», en GAMBETTA, D. (ed.), Making sense of suicide missions, Oxford University Press, Oxford, 2005, pp. 173-208. 
BOX, Zira, «Sacrificio y martirio nacional. Pasión, muerte y glorificación de José Antonio Primo de Rivera», Historia del Presente, 6, 2005, pp. 191228

BOX, Zira, «Poder creador de la muerte y el dolor: la consagración de los lugares del martirio en el regimen franquista», en CASQUETE, Jesús (ed.), Сотиnidades de muerte, Antropos, Madrid, 2009, pp. 55-94.

BRUBAKER, Roger, «Religion and Nationalism: Four Approaches», Nations and Nationalism, 18/1, 2012, pp. 2-20.

CASQUETE, Jesús, En el nombre de Euskal Herria. La religión política del nacionalismo vasco radical, Tecnos, Madrid, 2009.

CASTELLS, Luis, «Estudio preliminar», en ARANZADI, Engracio, La nación vasca, UPV-EHU, Bilbao, 2015, pp. 9-86.

CORCUERA, Javier, La patria de los vascos. Orígenes, ideología y organización del nacionalismo vasco, Taurus, Madrid, 2001.

DE PABLO, S., MEES, L., RODRÍGUEZ RANZ, J.A., El péndulo patriótico. Historia del Partido Nacionalista Vasco. 2 vols., Crítica, Barcelona, 2001.

DE PABLO, Santiago, «La guerra civil en el País Vasco: ¿un conflicto diferente?», Ayer, 50, 2003, pp.115-142.

DE PABLO, Santiago et alii, Diccionario ilustrado de símbolos del nacionalismo vasco, Tecnos, Madrid, 2012.

Documentos Y, Lur, San Sebastián, 1979.

ELORZA, Antonio, Un pueblo escogido. Génesis, definición y desarrollo del nacionalismo vasco, Crítica, Barcelona, 2001.

ELORZA, Antonio, Tras las huellas de Sabino Arana. Los orígenes totalitarios del nacionalismo vasco, Temas de Hoy, Madrid, 2005.

ELOSEGI, Joseba, Quiero morir por algo, s/n, 1971.

FERNÁNDEZ SOLDEVILLA, Gaizka, La voluntad del gudari, Tecnos, Madrid, 2016.

FRIEDLAND, R. y MOSS, K.B., «Thinking through religious nationalism», en SZAFRANIEC y HEMEL, E. (eds.), Words. Situating Religion in Language, Fordham University Press, New York, 2015, pp. 423-466..

GREENFELD, Liah, «The modern religion?», Critical Review, 10/2, 1996, 169191.

GRANJA, José Luis de la, El oásis vasco. El nacimiento de Euskadi en la República y la Guerra Civil, Tecnos, Madrid, 2007.

GRANJA, José Luis de la, Ángel o demonio: Sabino Arana. El patriarca del nacionalismo vasco, Tecnos, Madrid, 2015.

HAUPT, Heinz-Gerhard y LANGEWIESCHE, Dieter (eds.), Nación y religión en Europa. Sociedades multiconfesionales en los siglos XIX y XX, Institución Fernando el Católico, Zaragoza, 2010.

IBERO, E, Ami Vasco, Imprenta de E. Arteche, Bilbao. 1906. 
JULIÁ, Santos, Historias de las dos Españas, Taurus, Madrid, 2004.

KAPFERER, B., Legends of People, Myths of State, Berghahn Books, OxfordNew York, 2011 [1988] .

KÜHNE, T., Kameradschaft. Die Soldaten des nationalsozialistichen Krieges und das 20. Jahrundert, Vandenhoeck \& Ruprecht, Gotinga, 2006.

LAFON, A. La camaraderie au front: 1914-1918, Armand Colin, París, 2014.

LANGEWIESCHE, Dieter, La época del Estado-Nación en Europa, PUV, Valencia, 2012.

LINZ, Juan José, «El uso religioso de la política y/o el uso político de la religión: la ideología-sucedáneo versus la religión sucedáneo», Reis: Revista española de investigaciones sociológicas, 114, 2016, pp. 11-36.

MARTÍNEZ RUEDA, Fernando, «Telesforo Monzón, del nacionalismo aranista a Herri Batasuna: las claves de una evolución», Revista de Estudios Políticos, 174, 2016, pp. 267-297.

MARTÍNEZ RUEDA, Fernando, «Religión y nacionalismo vasco en el siglo XX: aproximación desde el sujeto a una relación compleja». Hispania Sacra, 140, 2017, pp. 721-733.

MARVIN, C. y INGLE, D. W., Blood sacrifice and the nation: Totem rituals and the American flag, Cambridge University Press, Cambridge, 1999.

MEES, Ludger, «Gernika», en DE PABLO, S. et alii (cords), Diccionario ilustrado de símbolos del nacionalismo vasco, Tecnos, Madrid, 2012, pp. 407429.

MEES, Luder, «Gerra euskal nazionalisten memorian», en ARROITA, I. y OTAEGI, L., Oroimenaren lekuak eta lekukoak. Gerra Zibilaren errepresentazio artistikoak vs. kontaera historiko-politikoa, UPV-EHU, Bilbo, 2015.

MONZÓN, Telesforo, Telesforo Monzón. Hitzak eta idazkiak, S.1, Jaizkibel, 1986.

MORO, Renato, «Rituales politicos/Religiones políticas», en CANAL, J. y MORENO LUZÓN, J. (eds.), Historia cultural de la política contemporánea, CEPC, Madrid, 2009, pp. 97-147.

MOSSE, George L. Soldados caídos. La transformación de la memoria de las guerras mundiales, Universidad de Zaragoza, Zaragoza, 2016 (1.a ed. Fallen soldiers. Reshaping the Memory of the World Wars, Londres, Oxford, U.P, 1990).

NÚÑEZ SEIXAS, Xose Manuel, «Los nacionalistas vascos durante la guerra civil (1936-1939): una cultura de guerra diferente», Historia Contemporánea 35, 2007, pp. 559-599.

NÚÑEZ SEIXAS, Xose Manuel, «Irlanda», en DE PABLO, S. et alii (coord.), Diccionario ilustrado de símbolos del nacionalismo vasco, Tecnos, Madrid, 2012, pp. 79-91. 
RICHARDS, M., Historias para después de una guerra. Memoria política y cambio social en España desde 1936, Pasado y Presente, Madrid, 2014.

RUBIO, José Antonio, «Memorias dispares. Las miradas de PNV y ETA en torno a la República y la Guerra Civil», en PASAMAR, G. (ed.), Ha estallado la memoria. Las huellas de la Guerra Civil en la Transición a la Democracia, Biblioteca Nueva, Madrid, 2014, pp. 135-156.

RUBIO, Coro y DE PABLO, Santiago, «Before and after the nation. Basque patriotic heroes, 1834-1939», Studies on National Movements, 3, 2015, pp. 2-26.

SÁEZ DE LA FUENTE, Izaskun, El Movimiento de Liberación Nacional Vasco, una religión de sustitución, Instituto Diocesano de Teología y Pastoral/Desclée de Brouwer, Bilbao, 2002.

SANTIAGO, J. A., Secularización y nacionalismo. Un análisis comparado de los nacionalismos vasco y quebequense, Tesis doctoral, Madrid, UCM, 2005.

SMITH, Anthony D., «The 'Sacred' Dimension of Nationalism», Millennium. Journal of International Studies, 29/3, 2000, pp. 791-814.

SMITH, Anthony D., Chosen peoples. Sacred sources of National Identity, Oxford University Press, Oxford, 2003.

SPONH, W., «Multiple Modernity, Nationalism and Religion: A Global Perspective», Current Sociology, 51 (3/4), 2003, pp. 265-286.

ZERTAL, I., «Sacrificados y santificados. El mito del Tel-hai y Trumpeldor en el sionismo», en CASQUETE, J. (ed.), Comunidades de muerte, Antropos, Madrid, 2009, pp.107-123.

ZUBRZYCKI, G., «Religion and Nationalism. A Critical Re-examination», en TURNER, B.S. (ed.), The New Blackwell Companion to the Sociology of Religion, Wiley-Blackwell, Oxford, 2010, pp. 606-625.

\section{Financiación}

Este texto se enmarca dentro del proyecto de investigación, subvencionado por el Ministerio de Economía y Competitividad (MICINN). Un modelo de prosopografía parlamentaria en perspectiva comparada: Cambio y continuidad en el Parlamento español 1810-1977 (ref. HAR2014-53974-P). Asimismo, dentro de la labor del Grupo de investigación consolidado del sistema universitario vasco (ref. IT-658-13), del Departamento de Educación, Universidades e Investigación del Gobierno Vasco. 


\section{Datos del autor}

Fernando Martínez Rueda (fernando.martinez@ehu.eus). Profesor Titular en el Departamento de Historia Contemporánea de la UPV/EHU. Es autor, entre otros libros, de Los poderes locales en Vizcaya: del Antiguo Régimen a la Revolución Liberal (1995) y coautor de Diccionario biográfico de los Parlamentarios de Vasconia, 1876-1939 (2007), Materiales para la Historia del Mundo Actual (2006) y Gaur Egungo Munduaren Historia (2011). Ha participado en numerosos proyectos y contratos de investigación como miembro del grupo consolidado de investigación "Biography \& Parliament». Sus últimas investigaciones se centran en el estudio del nacionalismo vasco del siglo Xx desde la perspectiva biográfica. Ha publicado más de una veintena de artículos en revistas especializadas sobre historia social y política del País Vasco contemporáneo. 